\title{
Evaluation of Total Antioxidant Capacity (TAC) of Saliva in Caries Active and Caries free Tribal School Going Children of Wardha District.
}

\author{
Dr. Sapna Randad ${ }^{1}$, Dr. Sudhindra Baliga ${ }^{2}$, Dr. Nilima Thosar ${ }^{3}$, \\ Dr. Nilesh Rathi ${ }^{4}$ \\ ${ }^{\text {I }}$ Postgraduate Student, Department Of Pedodontics And Preventive Dentistry, Sharad Pawar Dental College and Hospital, \\ Sawangi (Meghe), Wardha, Maharashtra, India.) \\ ${ }_{2}^{2}$ (Professor and Head, Department of Pedodontics and Preventive Dentistry, Sharad Pawar Dental College and Hospital, \\ Sawangi (Meghe), Wardha, Maharashtra, India) \\ ${ }^{3}$ (Professor, Department of Pedodontics and Preventive Dentistry, Sharad Pawar Dental College and Hospital, Sawangi \\ (Meghe), Wardha, Maharashtra, India) \\ ${ }^{4}$ (Reader, Department of Pedodontics and Preventive Dentistry, Sharad Pawar Dental College and Hospital, Sawangi \\ (Meghe), Wardha, Maharashtra, India)
}

\begin{abstract}
Aim: To evaluate the total antioxidant capacity (TAC) of saliva in caries active and caries free children from a tribal school of wardha district.

Materials and method: A total of 40 children aged between 5-14 years were selected by using simple random sampling. They were divided into two groups; Group I and Group II, comprising of age groups 5 to 9 years and 10 to 14 years, respectively. Both the groups were then sub-divided into caries-active and caries-free groups, with 10 children in each group. $2 \mathrm{ml}$ of unstimulated saliva was collected and was stored in glass vials at -20 degree celcius. Estimation of total antioxidant capacity of saliva of each sample was done by Phosphomolybdenum method.

Results: On comparison of TAC between the age group of 5-9 years, TAC in caries active children was $19.83 \mathrm{mcg} / \mathrm{ml}$ which was significantly higher than TAC obtained for caries free children which was $9.10 \mathrm{mcg} / \mathrm{ml}$. Similar results were found on comparison of TAC between both the groups between the age group of 10-14 years i.e. TAC was significantly higher in caries active children which was $31.82 \mathrm{mcg} / \mathrm{ml}$ than caries free children which was $15.33 \mathrm{mcg} / \mathrm{ml}$. On comparison of TAC between both the age groups, TAC was found to be significantly higher between the age group of 10-14 years which was $23.68 \mathrm{mcg} / \mathrm{ml}$ than between the age group of $5-9$ years which was $14.46 \mathrm{mcg} / \mathrm{ml}$.

Conclusion: Total antioxidant capacity of saliva was found to be more in caries active tribal children between the age group of 5-9 years and 10-14 years than caries free children. It was also reported that TAC was more in tribal children between the age group of 10-14 years than 5-9 year old tribal children.
\end{abstract}

Keywords: Caries, Saliva, Total antioxidant capacity of saliva

\section{Introduction}

Dental caries is the commonest chronic disease of mankind affecting the oral cavity. In simple words, it can be defined as a microbial disease of the calcified tissues of the teeth, characterized by the demineralization of the inorganic portion and destruction of the organic substance of the tooth. It affects people of both sexes with different socioeconomic strata, race, and age. It is also intensely affected by other factors like oral hygiene and saliva.

The saliva which is circulating in the mouth at any given time is termed as whole saliva and it consists of a mixture of secretions from the minor and major salivary glands and traces from the gingival crevicular fluid. It promotes oral health, therefore, decrease or lack of its secretion contributes to the disease process. The saliva by constantly bathing the oral mucosa and teeth, acts as a cleansing solution, a lubricant, a buffer, and an ion reservoir of calcium and phosphate, which are necessary for remineralization of initial carious lesions.[1] Saliva serves as a mirror of the body's health and has various defense mechanisms such as enzymatic and immunologic defense systems against bacteria, fungi, viruses, protection of mucosa and promotes its healing. One of such important defense mechanism is antioxidants system.[2,3]

Antioxidants have several health benefits that made their evaluation in disease process very popular. They are present in all body fluids and tissues including saliva which protect our body against endogenously formed free radicals (FR). Molecular oxygen is reduced to water and is accompanied by release of large free energy that can give rise to FR and or reactive oxygen species (ROS). Imbalance between the FRROS and the antioxidants system results in oxidative stress. This oxidative stress has been implicated as one of the important contributory etiologic factors in many of the oral diseases including dental caries.[4]

India has the largest population of the tribal people which constitute $8.61 \%$ of the total population of the country. Out of these, $52 \%$ of tribal population is below poverty line and 54\% tribals do not have access to economic assets such as communication and transport. The tribal population of India has remained socially and culturally distant from the mainstream Indian society until developmental activities in the tribal areas forced interactions between them. Wardha district, Maharashtra, is having a large number of tribal population and it is very essential to know the status of caries, periodontal diseases and general status of this population. Hence this study was aimed to estimate the total antioxidant capacity of unstimulated saliva in caries active and caries free tribal school going children of Wardha district. 


\section{Materials and Method}

The study was reviewed and approved by the Institutional ethics committee. The nature and purpose of the study were explained, and permission to conduct the study was obtained from the project officer of integrated tribal development project and principals of the schools. Consent forms were distributed among class teachers, so that they would forward it to the parents of school children to obtain their consent about their child's participation in the study.

A total of 40 children aged between 5-14 years were selected in the study. They were divided into two groups; Group I and Group II, comprising of age groups 5 to 9 years and 10 to 14 years, respectively. Both the groups were then subdivided into caries-active and caries-free groups, with 10 children in each group.

\subsection{Inclusion criteria}

Children who were free from systemic or local diseases, which affect salivary secretions.

Caries-active children having at least five decayed tooth surfaces.

Caries-free children having no caries.

\subsection{Exclusion criteria}

Patients who were physically and medically compromised.

Patients who were on medications.

Patients who had arrested carious lesions

\subsection{Saliva sample collection}

$2 \mathrm{ml}$ of unstimulated saliva was collected for the study, aseptically, in sterile plain plastic tubes. The patient was asked to sit by tilting the head downwards, the saliva was then allowed to accumulate in the floor of mouth which was then collected by asking the patient to spit. The samples were placed in a freezing box and stored at -20 degree celcius in a refrigerator till further processing. The total antioxidant capacity was measured by Phosphomolybdenum method and the results were compiled

\subsection{TAC evaluation by Phosphomolybdenum method}

The phosphomolybdenum assay used for determining the antioxidant capacity is based on the reduction of molybdenum (VI) - molybdenum (V) by the antioxidants and subsequent formation of a green phosphate/Mo (V) complex at an acidic $\mathrm{pH}$. About $0.3 \mathrm{ml}$ of the test sample was taken in a tube and mixed with $3 \mathrm{ml}$ of the reagent solution containing 0.6 $\mathrm{M}$ sulphuric acid, $28 \mathrm{mM}$ sodium phosphate and $4 \mathrm{mM}$ ammonium molybdate and incubated at $95^{\circ} \mathrm{C}$ for 90 min. Ascorbic acid was utilised as a reference standard. The absorbance of the mixture was then measured at $695 \mathrm{~nm}$ with blank. The antioxidant activity was expressed as the number of gram equivalents of ascorbic acid.[5]

\subsection{Statistical analysis}

Statistical analysis was done by using descriptive and inferential statistics applying student's unpaired t test. The software used in the analysis was SPSS 17.0 and graph pad prism 5.0 version. A 'p' value of $<0.05$ was considered as level of significance.

\section{Results}

On comparison of TAC between the age group of 5-9 years, TAC in caries active children was $19.83 \mathrm{mcg} / \mathrm{ml}$ which was significantly higher than TAC obtained for caries free children which was $9.10 \mathrm{mcg} / \mathrm{ml}$ [Table 2]. Similar results were found on comparison of TAC between both the groups between the age group of 10-14 years i.e. TAC was significantly higher in caries active children which was $31.82 \mathrm{mcg} / \mathrm{ml}$ than caries free children which was $15.33 \mathrm{mcg} / \mathrm{ml}$ [Table 3]. On comparison of TAC between both the age groups, TAC was found to be significantly higher between the age group of 10-14 years which was $23.68 \mathrm{mcg} / \mathrm{ml}$ than between the age group of 5-9 years which was $14.46 \mathrm{mcg} / \mathrm{ml}$ [Table 4].

\section{Discussion}

The majority of the tribal population groups in India stand much below the poverty line, suffering from an alarming malnutrition and high illiteracy. According to 2011 census $11.49 \%$ population in Wardha district is tribal in nature. They have limited access to dental care and are susceptible to oral diseases including dental caries. This is certainly true for the present study group for whom dental services are non existent, attributable to socioeconomic conditions, and fear of mixing with members of other communities.[6,7]

The use of saliva as a diagnostic fluid has become somewhat of a transitional success story during the last few decades. It is a complex biological fluid composed of enzymes, hormones, antibacterial constituents, electrolytes etc. [4] It serves as first line of defense against free radical-mediated oxidative stress. Unstimulated saliva has always been favoured in the determination of antioxidant defense parameters as compared to stimulated saliva as it is reported that TAC is higher in unstimulated saliva. Total antioxidant capacity was evaluated in our study as it is suggested that free radical/reactive oxygen species and antioxidant system appear to act in concert rather than alone, and measurement of any individual antioxidant may be less representative of whole antioxidant status. Also, the number of different antioxidants makes it difficult and expensive to measure each of them separately.[8]

In the present study it was observed that caries-free children had significantly lower levels of TAC when compared to caries-active children. The oral hygiene status of tribal children was poor and also exposure to caries was seen to be more, 
suggestive of increased TAC. Similar results were seen in study carried out by Tulunoglu et al [Table 1] who evaluated the TAC of saliva in 7-10 and 11-15 years of children and found that the TAC were higher in caries active children.[9] Preethi et al also estimated the TAC of saliva in 7-10 and 11-14 years of children, and reported that the mean level of TAC is increased in caries active children when compared to caries-free children.[10] Dodwad et al also studied TAC in caries active and caries free groups of children and showed increased TAC in caries active group. [1]The reason for increased TAC in caries active tribal children could be : It has been seen that salivary peroxidase system constitutes to be one of the major salivary antioxidant systems. Salivary peroxidase brings about the control of oral bacteria that form dental plaque, to imbalance in the ecology, which lead to dental caries. Salivary peroxidase catalyzes the peroxidation of thiocyanate ion (SCN-) to generate oxidation products (more stable OSCN-); this inhibits the growth and metabolism of many microorganisms thereby inhibiting caries or atleast slowing down the progress of caries.[11] It has been suggested that saliva is rich in antioxidants, mainly uric acid and with a lesser extent albumin, ascorbate, and glutathione, and all of these are proteins or have proteins in their structure. It has been found by various researchers that the salivary proteins were increased in individuals with dental caries. The increased TAC levels in saliva in caries active children may be attributed to elevated protein levels. $[10,12]$

In the present study it was found that TAC was more in children between the age group of 10-14 years than 5-9 year old children. It has been seen that availability of micronutrients is less in tribal children which may result in decreased TAC. But as the age advances the volume of consumption of food increases, this could be the reason for increase in TAC with increased age. Also, it has been seen that the immune status of an individual improves with age suggesting that TAC between the age group of 11-14 years is more. It is better developed in older age group and could therefore account for the increase in TAC of saliva in children belonging to older age group. Similar results were seen in study carried out by Dodwad et al who found increased TAC in children between the age group of 11-14 years than 7-10 year old children.[4]

\section{V. tables}

Table 1: Results of previous studies on total antioxidant capacity of saliva in relation to caries

\begin{tabular}{|l|l|}
\hline \multicolumn{1}{|c|}{ Name of the author } & \multicolumn{1}{c|}{ Results of studies on TAC } \\
\hline Tulunoglu et al[9] & Total antioxidant values were higher in caries active groups \\
\hline Uberos et al[13] & $\begin{array}{l}\text { Total antioxidant capacity of the saliva of patients with caries in } \\
\text { deciduous teeth was greater than among those without caries }\end{array}$ \\
\hline Prabhakar et al[14] & $\begin{array}{l}\text { Total antioxidant capacity of saliva increased } \\
\text { in caries active children }\end{array}$ \\
\hline Hegde et al[15] & Total antioxidant capacity of saliva increased in children with caries \\
\hline Preethi et al[10] & Total antioxidant capacity of saliva increased in caries active children \\
\hline Kumar et al[16] & $\begin{array}{l}\text { TAC of saliva increased in children with Severe early childhood caries } \\
\text { and increasing prevalence of dental caries predisposes to the increase } \\
\text { in TAC of saliva }\end{array}$ \\
\hline Dodwad et al[1] & $\begin{array}{l}\text { Total antioxidant capacity of saliva increased significantly in caries- } \\
\text { active children when compared to caries-free children }\end{array}$ \\
\hline Hegde et al1[7] & TAC level increases with increase in severity of caries \\
\hline Ahmadi-Motamayel et al[18] & $\begin{array}{l}\text { TAC was significantly higher in the saliva of caries active group } \\
\text { relative to the caries free subjects }\end{array}$ \\
\hline Mahjoub et al1[9] & $\begin{array}{l}\text { TAC levels and salivary total protein increased in children with severe } \\
\text { early childhood caries compared with caries-free children }\end{array}$ \\
\hline Pandey et al[20] & Total antioxidants in saliva increased with caries activity \\
\hline Muchandi et al[21] & Salivary TAC increases in patients with early childhood caries \\
\hline Silva et al[22] & $\begin{array}{l}\text { Salivary Total Antioxidant capacity was higher in children with early } \\
\text { childhood caries as compared to caries free children }\end{array}$ \\
\hline
\end{tabular}

Table 2: Comparison of TAC in 5-9 years age group

\begin{tabular}{|c|c|c|c|c|c|c|}
\hline & $\mathrm{N}$ & $\begin{array}{c}\text { Mean TAC } \\
(\mathrm{mcg} / \mathrm{ml})\end{array}$ & $\begin{array}{c}\text { Std. } \\
\text { deviation }\end{array}$ & Std. error mean & t-value & $\mathrm{p}$-value \\
\hline $\begin{array}{l}\text { Caries free } \\
\text { children }\end{array}$ & 10 & $9.10 \mathrm{mcg} / \mathrm{ml}$ & 2.32 & 0.73 & \multirow[t]{2}{*}{4.14} & \multirow{2}{*}{$\begin{array}{c}0.001 \\
S, p<0.05\end{array}$} \\
\hline $\begin{array}{l}\text { Caries active } \\
\text { children }\end{array}$ & 10 & $19.83 \mathrm{mcg} / \mathrm{ml}$ & 7.86 & 2.48 & & \\
\hline
\end{tabular}

Table 3: Comparison of TAC in 10-14 years age group

\begin{tabular}{|c|c|c|c|c|c|c|}
\hline & $\mathrm{N}$ & $\begin{array}{c}\text { Mean TAC } \\
(\mathrm{mcg} / \mathrm{ml})\end{array}$ & Std. deviation & $\begin{array}{c}\text { Std. error } \\
\text { mean }\end{array}$ & $\mathrm{t}$-value & $\mathrm{p}$-value \\
\hline $\begin{array}{c}\text { Caries free } \\
\text { children }\end{array}$ & 10 & $15.33 \mathrm{mcg} / \mathrm{ml}$ & 2.75 & 0.87 & & \\
\hline $\begin{array}{c}\text { Caries active } \\
\text { children }\end{array}$ & 10 & $31.82 \mathrm{mcg} / \mathrm{ml}$ & 10.73 & 3.39 & 4.70 & $\begin{array}{c}0.001 \\
\mathrm{~S}, \mathrm{p}<0.05\end{array}$ \\
\hline
\end{tabular}

Table 4: Comparison of TAC in 5-9 and 10-14 years age group

\begin{tabular}{|c|c|c|c|c|c|c|}
\hline & $\mathrm{N}$ & Mean TAC $(\mathrm{mcg} / \mathrm{ml})$ & Std. deviation & Std. error mean & t-value & p-value \\
\hline 5-9 yr old Children & 20 & $14.46 \mathrm{mcg} / \mathrm{ml}$ & 7.88 & 1.76 & & \multirow{2}{*}{0.006} \\
$\begin{array}{c}10-14 \text { yr old } \\
\text { children }\end{array}$ & 20 & $23.68 \mathrm{mcg} / \mathrm{ml}$ & 11.38 & 2.54 & 2.94 & S,p<0.05 \\
\hline
\end{tabular}




\section{Conclusion}

Total antioxidant capacity of saliva plays protective role in carious process. Availability of micronutrients and intake of healthy food in tribal children may help to increase TAC and counteract the carious process. The government must take initiative more seriously, sincerely, and effectively to create sustainable development by oral health programs and providing healthy food to them.

\section{References}

[1]. Dodwad R, Anupama V, Preeti BP. Estimation of total antioxidant capacity levels in saliva of caries-free and caries-active children. Contemporary Clinical Dentistry. Jan-Mar 2011;2(1):17-20

[2]. Schipper RG, Silletti E, Vingerhoeds MH. Saliva as research material: biochemical, physicochemical and practical aspects. Arch Oral Biol. 2007;52:1114-35.

[3]. Kohen R, Tirosh O, Kopolovich K. The reductive capacity index of saliva obtained from donors of various ages. Exp Gerontol. 1992;27:161-8.

[4]. Battino M, Ferreiro MS, Gallardo I, Newman HN, Bullon P. The antioxidant capacity of saliva. J Clin Periodontol. 2002;29:189-194.

[5]. Sahaa MR, Hasana SMR, Aktera R, Hossaina MM, Alamb MS, Alam MA, and Mazumder MEH. In vitro free radical scavenging activity of methanol extract of the leaves of Mimusops elengi Linn. Bangl. J. Vet. Med. 2008;6(2):197-202.

[6]. Baelum V, Fejerskov O, Karring T. Oral hygiene, gingivitis, and periodontal breakdown in Tanzanians J. Periodontol Res. 1986;21:221-232

[7]. Cutress TW, Powell RN, Ball ME. Differing profiles of periodontal diseases in two similar South Pacific island populations. Community Dent Oral Epidemiol. 1982;10:193-203.

[8]. Prior RL, Cao G. In vivo total antioxidant capacity: Comparission of different analytical methods. Free Radic Biol Med. 1999;27:1173-81.

[9]. Tulunoglu O, Demirtas S, Tulunoglu I. Total antioxidant levels of saliva in children related to caries, age, and gender. Int J Paediatr Dent. 2006;16:186-191.

[10]. Preethi B, Pyati A, Dodawad R. Evaluation of flow rate, ph, buffering capacity, calcium, total protein and total antioxidant levels of saliva in caries free and caries active children-An in vivo study. Biomed Res 2010;21:289-294.

[11]. Tenovuo J, Lehtonen OP, Aaltonen AS, Vilja P. Antimicrobial factors in whole saliva of human infants. Infect Immun. 1986;51:49-53.

[12]. Dodds MWJ, Johnson DA, Mobley CC, Hattaway KM. Parotid saliva protein profiles in caries-free and caries-active adults. Oral Surg Oral Med Oral Path Oral Radiol Endod. 1997; 83:244-257.

[13]. Uberos J, Alarcon JA, Penalver MA. Influence of the antioxidant content of saliva on dental caries in an at-risk community. Br Dent J. 2008 Jul $26 ; 205(2)$

[14]. Prabhakar A, Dodawad R, Os R Evaluation of flow rate, ph, buffering capacity, calcium, total protein and total antioxidant levels of salivain caries free and caries active children-an in Vivo study. Int J Clin Pediatr Dent. 2009 Jan;2(1):9-12

[15]. Hegde AM, Rai K, Padmanabhan V Total antioxidant capacity of saliva and its relation with early childhood caries and rampant caries. J Clin Pediatr Dent. 2009 Spring:33(3):231-4.

[16]. Kumar D, Pandey RK, Agrawal D, Agrawal D. An estimation and evaluation of total antioxidant capacity of saliva in children with severe early childhood caries. Int J Paediatr Dent. 2011 Nov;21(6):459-64

[17]. Hedge MN, Hegde ND, Ashok A, Shetty S. Evaluation of total antioxidant capacity of saliva and serum in caries-free and caries-active adults: an invivo study. Indian J Dent Res. 2013 Mar-Apr;24(2):164-7.

[18]. Ahmadi-Motamayel F, Goodarzi MT, Hendi SS, Kasraei S, Moghimbeidi A. Total antioxidant capacity of saliva and dental caries. Med Oral Patol Oral Cir Bucal. 2013 Jul 1;18(4):e553-6.

[19]. Mahjoub S, Ghasempour M, Gharage A, Bijani A, Masrourroudsari J. Comparison of total antioxidant capacity in saliva of children with severe early childhood caries and caries-free children. Caries Res. 2014;48(4):271-5

[20]. Pandey P, Reddy NV, Rao VA, Saxena A, Chaudhary CP. Estimation of salivary flow rate, pH, buffer capacity, calcium, total protein content and total antioxidantcapacity in relation to dental caries severity, age and gender. Contemp Clin Dent. 2015 Mar;6(Suppl 1):S65-71

[21]. Muchandi S, Walimbe H, Bijle MN, Nankar M, Chaturvedi S, Karekar P. Comparative evaluation and correlation of salivary total antioxidant capacity and salivary $\mathrm{pH}$ in caries-free and severe early childhood caries children. J Contemp Dent Pract. 2015 Mar 1;16(3):234-7

[22]. Silva PV, Troiano JA, Nakamune AC, Pessan JP, Antoniali C. Increased activity of the antioxidants systems modulate the oxidative stress in saliva of toddlers with early childhood caries. Arch Oral Biol. 2016 Jun 4;70:62-66 